\title{
ASPECTS OF HIGH EARTHQUAKE RISK GOVERNMENT BUILDINGS
}

\author{
D. Sinclair*
}

\section{INTRODUCTION}

During the last 150 years 19 large shallow earthquakes are reported to have occurred, 6 of these between 1929 and 1942 . From 1940, when instrumentation of earthquakes began, up to 1968 an additional 33 only slightly less in size were recorded. Any of these events taking place close to built up areas would have resulted in serious damage and collapse of many unreinforced masonry buildings.

After the 1931 Napier earthquake which almost demolished the business area, building codes required earthquake forces to be taken into account and by about 1935 these requirements were generally being incorporated into building designs.

This meant however that there were large number of unreinforced masonry buildings constructed prior to 1935 throughout N.Z. which were susceptible to damage or collapse during a damaging earthquake. In most towns and cities these comprised about $2 / 3$ of all commercial buildings. Their size ranges up to about $100,000 \mathrm{sq}$. ft. in floor area and a maximum height of about 5 storeys.

Such buildings usually attact large earthquake forces because of their weight and rigidity and this combined with a brittle construction consisting of many small masonry units joined only by mortar of generally low strength, and the fact that floors and roofs only rest on the walls and do not prevent their outwards collapse, makes them especially prone to severe damage.

\section{HISTORY}

The risk to life and property that these buildings represent has long been recognised. A 1931 report is the earliest so far found on a high earthquake risk government building and from that time attention has been given to improvement of these buildings, particularly by the removal of hazards such as parapets, etc. In more recent years however the magnitude of the problem has become more apparent, it is estimated that perhaps $\$ 200$ million of government buildings are involved. In 1965 the late Mr. J. A. R. Johnston devised and introduced a classification system so that government buildings could be surveyed, classified and replaced in an orderly and logical way. This system is still operating with considerable success, with only minor development and elaboration by others, and

* Building Survey Engineer, Structural Design Office, Ministry of Works, Wellington. was adopted by the N.Z. National Society for Earthquake Engineering as the basis for the code of practice which is currently being introduced.

Essentially this code was developed to guide local bodies in a uniform approach where they are carrying out surveys under the 1968 amendment to the Municipal Corporations Act 1954. This amendment gives local bodies adopting it powers with respect to buildings likely to be dangerous in earthquakes.

Both the Society's code of practice and the MOW system enable the buildings, when classified, to be sorted into an order of priority for attention. In the case of the code no total period is given but the MOW programme is based on an original premise that all buildings would be dealt with in 30 years from 1965. This period must be regarded however as somewhat flexible because it is necessarily affected by unforeseen factors such as the state of the economy and the amount of money provided to deal with high risk builaings.

\section{PROGRESS ON SURVEYS}

The largest proportion dealt with to date are those constructed of cavity brick or stone exterior bearing walls, interior brick walls and partitions, concrete strip footings, timber floors and roof framing. The floors are sometimes supported internally on cast iron columns. Even though all the buildings were not designed to be earthquake resistant some would perform much better than others because the designers displayed greater structural intuition in the provision of resisting elements and in tying the parts together.

In the early stages of the survey some 900 timber buildings were surveyed, but because of the generally low risk and pressure to make progress with masonry buildings, timber buildings are not now being surveyed except in special cases.

Some post 1935 buildings have been surveyed and several of these proved to be structurally unsatisfactory.

A large number of private buildings have been surveyed to determine their suitability for government lease. It is still not possible to avoid such leases entirely but they are extended or entered into only if no better building is available and for the shortest possible time which is never longer than the end of the replacement period in the MOW system.

Since 1965 about 1,500 masonry 
buildings have been surveyed and it is estimated that about 3,000 buildings will have been examined before all of the unreinforced masonry type have been identified.

When a building has been surveyed and classified it is allocated a replacement period. If there are hazardous features on the building it is placed in a special category until the hazards are removed after which the replacement period is decided.

Replacement periods have so far been allotted strictly on the basis of the present classification system but when the total survey is completed in the near future, these will be reviewed. It is expected that too many buildings in some categories will have been programmed for attention at the same time. A closer examination of some of them to establish lesser differences not brought out by the classification system will be necessary so that replacement times can be more evenly spread throughout the 30 year period. It may be necessary to carry out limited strengthening in some cases where replacement is not possible at the desired time.

There are other factors also which affect the programme such as the necessity to replace buildings for other than structural reasons and the 30 year period itself may have to be modified in order to fit in with the money actually made available for replacements.

\section{WORK DONE AND PROPOSED ON SURVEYED BUILDINGS}

The first action usually taken is the removal of hazards. Brick chimneys if not in use can be reduced to roof or ceiling level (depending on the working space available), the chimney capped and the roof repaired. If the chimney is in use the flue can be replaced in steel to a height that is safe from fire protection considerations. As it is usually found that the roof design is inadequate for tying the gable to it, brick or stone gables are being replaced in timber or other lighter weight materials.

High parapets are normally replaced with a reinforced concrete band or parapet dowelled into the supporting brickwork and returned around corners for a suitable distance to give more stability. Dangerous ornamentation is taken down.

In a few exceptional cases where a building has a short "Iife" hazards are allowed to remain but the "life" is reduced by an appropriate amount.

It has been found structurally impractical to strengthen unreinforced masonry buildings for an indefinite life, but possible to strengthen some of the less dangerous buildings to give a satisfactory additional "life". A widely adopted figure in N.Z. and overseas is that a proposal for upgrading is not economic if the structural improvements, including those found necessary when the building is opened up, fire protection and architectural requirements, including renewing services exceeds about $1 / 3$ of the replacement cost.
So far three buildings have been strengthened but three others thought to be suitable for strengthening were not after all the factors had been considered. It may be possible that a greater number of buildings having inherently structurally better features and therefore fewer classification system demerits may be found suitable for strengthening as they approach their replacement dates.

Where unreinforced masonry buildings have become surplus to requirements and the land is not required for a crown purpose they are offered for sale to the private sector provided the building's programmed life is not exceeded and provided the prospective owner has been asked in writing to obtain a structural engineer's report. Where an old building has been offered for sale and no buyer appears the building would be demolished and the cleared site sold. A building whose "life" has been exceeded is demolished.

\section{HISTORIC BUILDINGS}

This group of buildings includes many earthquake hazardous structures. No accepted scale exists that allows balancing risk of life against aesthetic values. Unfortunately sufficient funds are rarely available to carry out strengthening to a degree required for an indefinite life. The engineer has no choice but to give as much information as is available on the risks involved. The final decision and responsibility must rest with the community.

Regardless of the funds available the problem is made extremely difficult because many hazardous features cannot be removed without destroying the texture and appearance of the building. For the same reasons some of the most effective strengthening methods, for example external corsetting or internal treatments such as guniting, cannot be used.

The retention of inadequately strengthened historic buildings can be more readily justified if located away from busy streets and used only occasionally by small numbers of people.

\section{ADDITIONAL PERIODIC INSPECTIONS OF BUILDINGS SURVEYED}

Even after the main body of building surveys has been completed it will be required to inspect buildings for lease purposes, to ascertain any deterioration, for change of use, additonal floor loads, etc., and at these times it may be convenient also to review the previous classificationsgiven for these new conditions. Post 1935 buildings will be given greater attention than previously.

\section{EMERGENCY DOCUMENTS}

It is intended that booklets about A4 size be prepared for each building surveyed containing reduced copies of any relevant plans available, the building survey form, photos, and any other information such as the details of existing defects and damage. Strategically located such documents will allow the inspecting engineer in the event of a damaging earthquake to prepare a report 
more promptly.

\section{CONCLUSION}

The MOW has for some 10 years replaced the highest earthquake risk buildings and reduced the hazards on others. In doing so it has set an example contributing to the introduction of legislation requiring similar action with regard to the private sector buildings. The MOW building survey system has proved itself effective in allowing systematic replacement of high earthquake risk buildings.

\section{ACKNOWLEDGEMENTS}

The author wishes to gratefully acknowledge the Commissioner of Works' permission to publish this paper. 